\title{
Flight muscle shape reliably predicts flight muscle mass of migratory songbirds: a new tool for field ornithologists
}

Ulf Bauchinger ${ }^{1,2,3}$ Scott R. McWilliams ${ }^{3}$, Harald Kolb ${ }^{1}$, Vladimir Popenko ${ }^{4}$, Edwin R. Price ${ }^{5}$ and Herbert Biebach ${ }^{1}$

${ }^{1}$ Max Planck Institute for Ornithology, Seewiesen, Germany

${ }^{2}$ Department Biologie II, Ludwigs-Maximilians-Universität München, Germany

${ }^{3}$ Dept. Natural Resources Science, 105 Coastal Institute in Kingston, University of Rhode Island, Kingston, RI 02881, USA.

${ }^{4}$ Azov-Black Sea Ornithological Station, Melitopol, Ukraine

${ }_{5}$ Department of Biology, Advanced Facility for Avian Research, University of Western Ontario, London, Ontario, Canada

Author for correspondence:

Ulf Bauchinger

Dept. Natural Resources Science

105 Coastal Institute in Kingston

University of Rhode Island, Kingston

RI 02881, USA

Fax: ++01401 8744561

e-mail: ulf@etal.uri.edu

Keywords:

Calibration, validation, pectoral muscle, body condition, passerine 


\begin{abstract}
The pectoral muscle is the biggest organ within a passerine bird. It provides flight locomotion and is known to act as a protein source during periods with increased protein demands or decreased protein availability. The mass of the flight muscle is dynamic and changes during juvenile growth, reproduction, seasonal acclimatization, fasting and migration. Thus a tool that accurately and non-invasively quantifies this phenotypic flexibility in flight muscle mass is of interest to ornithologists. We provide a calibration and validation of a "muscle-meter" device designed to accurately measure the shape of the flight muscle. For two species of different size, the European starling (Sturnus vulgaris) and the garden warbler (Sylvia borin), we compared the accuracy and precision of different linear regression models for predicting flight muscle mass. The multi factorial linear regression model with the most support for both species included "muscle-meter score" $\left(\mathrm{mm}_{\text {score}}\right)$, tarsus length and body mass $\left(m_{\mathrm{b}}\right)$, although a simpler model with $\mathrm{mm}_{\text {score }}$ and $m_{\mathrm{b}}$ had as much support for predicting flight muscle mass of European starlings. A validation exercise revealed that flight muscle mass of these two species could be estimated with a relative error of about $3 \%$. The "muscle-meter" is a simple device, easy and quick to handle, that can reliably and non-invasively estimate flight muscle mass of captive and wild birds when used in conjunction with standard measurements of tarsus length and $m_{\mathrm{b}}$.
\end{abstract}

\title{
Zusammenfassung
}

\section{Berechnung der Flugmuskelmasse von Zugvögeln anhand der Flugmuskelform: ein neues Hilfsmittel für Feldornithologen}

Der große Flugmuskel (Musculus pectoralis) ist das größte Organ im Singvogelkörper. Er ermöglicht das Fliegen, stellt aber auch eine körpereigene Proteinquelle dar, die bei erhöhtem Proteinbedarf oder reduzierter Proteinverfügbarkeit genutzt wird. Die Masse des großen Flugmuskels zeigt ein dynamisches Verhalten und ändert sich beispielsweise während des jugendlichen Wachstums, der Reproduktion, der jahreszeitlichen Anpassung, 
des Fastens und des Zuges. Ein Hilfsmittel, zu einer exakten und nicht-invasiven Erfassung dieser phänotypischen Flexibilität des Flugmuskels ist deshalb von großem Interesse für Ornithologen. Hierzu stellen wir hier das 'Muskel-Meter' sowie seine Kalibrierung und Validierung, zur exakten Messung der Form des Flugmuskels vor. Bei zwei unterschiedlich großen Vogelarten, dem Europäischen Star (Sturnus vulgaris) und der Gartengrasmücke (Sylvia borin), haben wir multifaktorielle lineare Regressionsmodelle auf ihre Genauigkeit hinsichtlich einer präzisen Voraussage der Flugmuskelmasse überprüft. Das Regressionsmodell mit der besten Anpassung an die empirischen Daten beider Vogelarten beinhaltet den 'Muskel-Meter Score' $\left(\mathrm{mm}_{\text {score }}\right)$, die Tarsuslänge und die Körpermasse $\left(m_{\mathrm{b}}\right)$. Das einfachere Modell mit $\mathrm{mm}_{\text {score }}$ und $m_{\mathrm{b}}$ erzielt eine ähnliche Übereinstimmung, allerdings nur für den Europäischen Star. Eine Validitätsprüfung zeigt, dass die Flugmuskelmasse der beiden Arten mit einem relativen Fehler von 3\% abgeschätzt werden kann. In Kombination mit Standardmessungen, wie der Tarsuslänge und der Körpermasse, ist somit das Muskel-Meter bestens für eine rasche und genaue, nicht-invasive Abschätzung der Flugmuskelmasse von Wildvögeln und Vögeln in Tierhaltung geeignet. 
The pectoral muscle in birds amounts to $10-25 \%$ of body mass for most actively flying species with some extreme cases of even more than $30 \%$ (Hartman 1961). It is thus the biggest single organ within a passerines' body. Besides its main function for flight locomotion it serves as a protein source during times with high protein demands or low protein intake (Jones and Ward 1976; Piersma and Jukema 1990; Houston et al. 1995; Cottam et al. 2002; for review see: Piersma and Lindstöm 1997; Bauchinger and Biebach 1998; Jenni and Jenni-Eiermann 1998). The pectoral muscle generates the force for the down stroke of the wing, while the supracoracoideus muscle lifts the wing. Both muscles together are often referred to as flight muscle. Because the pectoral muscle roughly contributes to about $90 \%$ of the flight muscle mass, with the remainder being associated to the supracoracoideus muscle (Hartman 1961), the term flight and pectoral muscle are often used interchangeably.

Mass of the flight muscle in birds changes during the annual cycle and especially during growth, migration, egg laying, molt and seasonal acclimatization (for review see: Piersma and Lindström 1997; Bauchinger and Biebach 1998, Cottam et al. 2002, Piersma and Drent 2003, Dietz et al. 2007, Swanson 2010). In general, flight muscle mass is positively related to intraspecific variation in body size (Calder 1984). Flight muscle mass often tracks body mass $\left(m_{\mathrm{b}}\right)$ during various conditions like flight, starvation and re-feeding (Lindström et al. 2000), during the annual cycle (Dietz et al. 2007) and during migration (Fry et al.1972; Marsh 1984; Bauchinger and Biebach 2001; Dietz et al. 2007). However, changes in flight muscle mass are not always associated with changes in body mass. Eared grebes (Podiceps nigricollis) increased $m_{\mathrm{b}}$ while flight muscle mass decreased when they were flightless at an autumn staging ground, and then $m_{\mathrm{b}}$ decreased while flight muscle mass increased just prior to the grebes leaving the staging area (Gaunt et al. 1990, Jehl 1997). Migratory garden warblers (Sylvia borin) during migration showed a general positive relationship between flight muscle mass and $m_{\mathrm{b}}$ when sampled immediately before and after long flight periods (Bauchinger and Biebach 2001). However, garden warblers arriving at stopover sites at the edge of an ecological barrier and prior to the flight across this barrier had relatively heavy flight muscle mass even though $m_{\mathrm{b}}$ was relatively low (Bauchinger and Biebach 2005).

Several methods are available for non-invasively estimating flight muscle mass of larger birds, although those used for songbirds provide only qualitative indices of flight muscle mass that are subjectively assessed. Measuring flight muscle thickness by use of 
ultrasound has proven a useful method to estimate flight muscle mass in different wader species (Lindsström et al. 2000, Dietz et al. 1999; Dietz et al. 1999b). Dietz et al. (1999) report that flight muscle mass of two wader species can be estimated with an individual error of 20 to $25 \%$. Contouring the shape of the muscle with solder wire over a defined point at the Carina sterni provided a reliable estimate of flight muscle mass in gulls (Bolton et al. 1991) and geese (Nyeland et al. 2003). Selman and Houston (1996) molded the shape of the flight muscle of passerine birds into a gel used for dental imprints and quantified the volume of the flight muscle from the negative imprint. An index of flight muscle size of geese and songbirds was obtained by scoring the shape of the flight muscle (e.g., concave, straight, convex, bulging) on both sides of the Carina sterni (Bairlein 1995; Nyeland et al. 2003). The advantage of such an index is that the muscle score is simple, repeatable and fast, and can thus be performed on hundreds of individuals at ringing stations. However, such indices provide an estimate of only relative flight muscle shape and not flight muscle mass (but see for geese: Nyeland et al. 2003). Other techniques measure flight muscle thickness or shape, but require time and handling effort, more than one person, or costly equipment which limits their usefulness especially for studies of freeliving birds (see Bairlein 1995).

Herein, we describe a new technique to estimate flight muscle shape that, when combined with other size measures, it can quickly and reliably estimate flight muscle mass of free-living wild-caught birds. The "muscle-meter" device is simple, easy to handle by one person, and provides fast yet accurate measurements of the flight muscle shape. For two species of different size, the European Starling (Sturnus vulgaris) and the garden warbler (Sylvia borin), we compared the accuracy and precision of different linear regression models for predicting flight muscle mass. Our data sets were as heterogeneous as possible, providing maximum variability in terms of structural size, $m_{\mathrm{b}}$ and flight muscle mass in order to demonstrate the predictability of flight muscle mass by application of "muscle-meter" measurements.

\section{Materials}

Accurate use of any non-invasive technique for estimating body composition of free-living birds requires performance of a validation study (Scott et al. 2001). One validation approach involves building predictive models for estimating flight muscle mass using a subset of birds (calibration) and then using the models to predict flight muscle 
mass in another subset of birds that were not used to develop the predictive models (validation). We predicted flight muscle mass $\left(m_{\mathrm{fm}}\right)$ of European starlings (Sturnus vulgaris) and garden warblers (Sylvia borin) given their body mass, tarsus length, and "muscle-meter" measures of their flight muscle shape. Body mass of European Starlings ranges between 60 and $90 \mathrm{~g}$ (Snow et al. 1998), whereas body mass of garden warblers ranges between 15 and $25 \mathrm{~g}$ (Bairlein 1987; Bairlein 1991), with extreme values beyond those ranges for both species. All birds used in this contribution were part of investigations on migration and flight physiology, and so spanned the range of documented body mass (and flight muscle mass). We captured 116 starlings during August in Ontario (43 $10^{\circ} \mathrm{N}$; $\left.81^{\circ} 19^{\top} \mathrm{W}\right)$, Canada, and maintained them for up to four months in captive facilities at the AFAR (Advanced Facility for Avian Research) facility at University of Western Ontario. A total of 45 garden warblers were used in this study with 14 birds captured in Turkey $\left(36^{\circ} 40^{`} \mathrm{~N} ; 3^{\circ} 05^{\prime} \mathrm{E}\right)$ during autumn migration (Biebach 1998, Bauchinger and Biebach $2001)$ and 31 birds captured on Crimea peninsula $\left(45^{\circ} 25^{\prime} \mathrm{N} ; 32^{\circ} 32^{\prime} \mathrm{E}\right)$ in Ukraine during spring migration. Data sets for both species were decidedly heterogeneous with respect to sex, body size and body mass.

For all birds we measured tarsus length, (Svenson 1992), $m_{\mathrm{b}}$, and the shape of the flight muscle at a defined location (subsequently, $\mathrm{mm}_{\text {score }}$ ). Figure 1 shows the "musclemeter" device and describes the measurement method in detail. We took three consecutive measures of $\mathrm{mm}_{\text {score }}$ for each starling and then used the mean of these three measures for subsequent modeling, whereas we took only one measure of $\mathrm{mm}_{\text {score }}$ for each garden warbler. Subsequently, birds were anesthetized under Isoflurane and killed by cervical dislocation and the left pectoral and supracoracoideus muscles were dissected. Fresh mass of the muscles was determined immediately for starlings and within weeks upon storage in liquid nitrogen for warblers (for methods see Bauchinger and Biebach 2001). For calculation of flight muscle mass $\left(m_{\mathrm{fm}}\right)$ of each bird we combined the samples of the pectoral and the supracoracoideus muscles, multiplied those by two, and hereafter refer to this as $m_{\mathrm{fm}}$. We calculated repeatability for the measurements of $\mathrm{mm}_{\text {score }}$ by use of the 'muscle-meter' according to method described by Lessels and Boag (1987).

Procedure for developing predictive models

The complete data set for each species was used to build regression models with flight muscle mass as the dependent variable and all possible combinations of the 
following independent variables: tarsus length, $\mathrm{mm}_{\text {score }}$, or $m_{\mathrm{b}}$. We used the $\mathrm{r}^{2}$-value and the Akaike Information Criterion (AICc) for low sample size to evaluate which model(s) explained the most variance and had the highest level of support (Burnham and Anderson 2002). All data were tested for normality (K-S test) prior to regression analysis. Linear regression models were used to describe the relationship between the independent variables to $m_{\mathrm{fm}}$, because cubic and quadratic models did not explain more of the variance and were more parsimonious.

We estimated the accuracy and precision of the predictive models using a validation approach. We randomly selected $88 \%$ of the birds of each species (105 European starlings and 39 garden warbler) and built regression models with flight muscle mass as the dependent variable and all possible combinations of the following independent variables: tarsus length $\mathrm{mm}_{\mathrm{score}}$, or $m_{\mathrm{b}}$. We then estimated the $m_{\mathrm{fm}}$ of the remaining birds (11 European starlings and 6 garden warblers) using these regression models built with the $88 \%$ subset of birds. To ensure that the birds used to build each model spanned the full range of body mass for that species, we assigned individuals with the two most extreme values for tarsus length, $\mathrm{mm}_{\text {score }}$ and $m_{\mathrm{b}}$ of each of the two species to the calibration group used to build the model, and randomly selected the remaining individuals for the calibration and the validation group. We estimate the absolute and relative error terms for the predictive models for the comparison between the estimated $m_{\mathrm{fm}}$ and the $m_{\mathrm{fm}}$ value determined after dissection by weighing the tissue, because coefficients of determination are not always indicative of error when evaluating the usefulness of regression equations (e.g., Skagen et al. 1993). Absolute error was calculated as predicted-actual, and relative error as [100 ( predicted - actual ) / actual]. We used PASW Statistics (version 18) for the analysis.

\section{Results}

Distribution and range of measurements

We used untransformed tarsus length, $\mathrm{mm}_{\text {score }}$ and $m_{\mathrm{b}}$ to predict $m_{\mathrm{fm}}$ because these data were normally distributed (K-S test $\mathrm{p}>0.40$ for all parameters and both species). For starlings $(\mathrm{n}=115)$, the range for tarsus length was $5.1 \mathrm{~mm}$ ( $\min$. to max. 26.7 to $31.8 \mathrm{~mm}$ ), the range for $\mathrm{mm}_{\text {score }}$ was $3.46 \mathrm{~mm}(-6.27$ to $-2.79 \mathrm{~mm})$, the range for $m_{\mathrm{b}}$ was $26.2 \mathrm{~g}(55.3$ to $81.5 \mathrm{~g}$ ), and the range for flight muscle mass was $7.44 \mathrm{~g}$ (10.86 to $18.30 \mathrm{~g})$. For garden warblers $(\mathrm{n}=45)$, the range for tarsus length was $2.7 \mathrm{~mm}$ (min. to max., 18.9 to $21.6 \mathrm{~mm}$ ), 
the range for $\mathrm{mm}_{\text {score }}$ was $1.75 \mathrm{~mm}(-3.74$ to $-1.99 \mathrm{~mm})$, the range for $m_{\mathrm{b}}$ was $12.8 \mathrm{~g}(14.7$ to $27.5 \mathrm{~g}$ ) and range for flight muscle mass was $1.26 \mathrm{~g}$ (2.23 to $3.49 \mathrm{~g})$.

In European starlings measurements of $\mathrm{mm}_{\text {score }}$ showed a repeatability (r) of $0.79(\mathrm{r}$ $=\mathrm{s}_{\mathrm{A}}^{2} /\left(\mathrm{s}^{2}+\mathrm{s}_{\mathrm{A}}^{2}\right)$; where $\mathrm{s}_{\mathrm{A}}^{2}=0.39$ is the among group variance component and $\mathrm{s}^{2}=0.10$ the within-group variance component).

\section{Calibration and Akaike information criterion}

We compared $\mathrm{r}^{2}$-values and Akaike information criteria for the seven linear regression models for each species with flight muscle mass as the dependent variable and all possible combinations of the following independent variables: tarsus length, $\mathrm{mm}_{\text {score }}$, and $m_{\mathrm{b}}$ (Table 1). All starlings $(n=116)$ and garden warblers $(n=45)$ were used to build these regression models. $r^{2}$-values increased and Akaike information criteria decreased from single factor to multiple factor regression analysis and in both species the linear regression model combining the three factors of tarsus length, $m_{\mathrm{b}}$ and $\mathrm{mm}_{\mathrm{score}}$ had the highest $r^{2}$-values and substantially more support based on Akaike information criteria. For European starling, both, a two-factor linear regression model and the three-factor linear regression model provide good support based on Akaike information criteria (please see below). The three-factor linear regression model for predicting flight muscle mass $\left(m_{\mathrm{fm}}\right)$ was as follows for each species:

European starling:

$$
m_{\mathrm{fm}}=3.797+\left(0.886 \mathrm{~mm}_{\mathrm{score}}\right)+\left(0.189 m_{\mathrm{b}}\right)+(0.059 \text { tarsus length })(\text { eq. } 1)
$$

Garden warbler:

$$
m_{\mathrm{fm}}=-1.212+\left(0.293 \mathrm{~mm}_{\text {score }}\right)+\left(0.045 m_{\mathrm{b}}\right)+(0.199 \text { tarsus length })(\text { eq. } 2)
$$

For garden warblers, the three-factor model (eq 2) was the only model that was substantially supported, with $\Delta$ AICc values of nine and higher for the remaining models (Table 1). For European starlings, both the three-factor model (eq 1) as well as the twofactor model (eq 3) were substantially supported (Table 1), with $\Delta$ AICc values of zero for the two factorial linear regression model (eq. 3), and a $\Delta$ AICc value of 2.9 for the three factorial model (eq. 2). All other models for the estimation of $m_{\mathrm{fm}}$ for European starlings failed to substantially explain variation in these data (Table 1). This most parsimonious two-factor linear regression model for predicting flight muscle mass $\left(m_{\mathrm{fm}}\right)$ was as follows: 
European Starling:

$$
m_{\mathrm{fm}}=5.003+\left(0.860 \mathrm{~mm}_{\text {score }}\right)+\left(0.195 m_{\mathrm{b}}\right)(\text { eq. } 3) .
$$

Validation

Consistent with the above results from the calibration, when we compared predicted and actual $m_{\mathrm{fm}}$ using the validation subset of both bird species, the absolute and relative errors for estimated $m_{\mathrm{fm}}$ were lowest for the three-factor linear regression model (Table 2). Error terms for both species increased with increasing $\triangle$ AICc values. For the European starling, mean absolute error increased from $0.39 \mathrm{~g}$ for the three-factor model to $1.16 \mathrm{~g}$ for the single-factor model that included only tarsus length. For the garden warbler, mean absolute error increased from $0.12 \mathrm{~g}$ for the three-factor model to $0.27 \mathrm{~g}$ for the single-factor model that included $\mathrm{mm}_{\text {score }}$. Mean relative error for the three-factor model was $2.6 \%$ for the European starling and 3.1 for the garden warbler and it increased to 7.8 $\%$ and $9.1 \%$, respectively, for the single-factor models.

\section{Discussion}

Our calibration and validation experiments for two passerines show that using the newly developed "muscle-meter" in conjunction with measurements for whole animal mass and structural size results in reliable estimates of $m_{\mathrm{fm}}$ in live birds. In order to obtain estimates for $m_{\mathrm{fm}}$ with a relative error margin of about $3 \%$, two additional measurements were included in the linear regression model, namely the tarsus length as a measure of structural size and $m_{\mathrm{b}}$. Both these additional measures are routinely collected at ringing stations. For European starling use of the $\mathrm{mm}_{\text {score }}$ in conjunction with $m_{\mathrm{b}}$ already provides reliable estimates of $m_{\mathrm{fm}}$, even without additional measurements of the tarsus length. Whether or not tarsus length is taken into account for estimating $m_{\mathrm{fm}}$ does not alter the relative error margins (Table 2). Besides providing a reliable estimate of flight muscle mass of an individual captured once (as commonly occurs at a ringing station), this technique allows repeated measurements of the same individual either in captive studies or in mark re-capture studies in the field.

We used the "muscle-meter" with two different mouth gaps, $10 \mathrm{~mm}$ for bigger birds like the European starlings and $6 \mathrm{~mm}$ for smaller birds like the garden warbler, and this provided accurate estimates of the $m_{\mathrm{fm}}$ with similar relative error ( 3 and $4 \%$, 
respectively) when used in conjunction with measurements for tarsus length and $m_{\mathrm{b}}$. We estimated the $m_{\mathrm{fm}}$ of European starlings with $0.39 \pm 0.33 \mathrm{~g}$ absolute error which was relatively small given mean flight muscle of starlings was $14.97 \pm$ SD 5.16 g. Likewise, we estimated the $m_{\mathrm{fm}}$ of garden warblers with $0.12 \pm 0.09 \mathrm{~g}$ absolute error which was relatively small given mean flight muscle of these warblers was $2.89 \mathrm{~g} \pm \mathrm{SD} 0.29$. Although we measured $\mathrm{mm}_{\text {score }}$ only once for each garden warbler and repeatability for the measurements of $\mathrm{mm}_{\text {score }}$ is high ( 0.79 for the starlings), we recommend three repeated measures of the $\mathrm{mm}_{\text {score}}$, as done for each European Starling, in order to ensure the accuracy and precision of these estimates.

The accuracy and precision of the muscle meter is sufficient for studying phenotypic flexibility of flight muscle in wild birds. Flight muscle mass of garden warblers decreased on average by $0.51 \mathrm{~g}$ during their spring flight across the Sahara desert (Bauchinger et al. 2005) which is more than four times the error that we report for the estimates of $m_{\mathrm{fm}}$ from the "muscle-meter" measurements in conjunction with tarsus length and $m_{\mathrm{b}}$. Similarly, $m_{\mathrm{fm}}$ of garden warblers increased on average by $0.27 \mathrm{~g}$ during molt while in the African wintering area (Bauchinger and Biebach 2006), which is more than double the error that we report for the estimates of $m_{\mathrm{fm}}$ from the "muscle-meter" measurements. Other studies on phenotypic mass changes in garden warblers indicate similar mass changes that could be assessed using the muscle meter (Hume and Biebach 1996, Schwilch et al. 2002). In European starlings the maximum difference in fresh $m_{\mathrm{fm}}$ between exercised and unexercised birds amounted to $1.8 \mathrm{~g}$ (based on mass for pectoral muscle, Swaddle and Biewener 2000) and this is more than four times higher than the error that we report for the estimates of $m_{\mathrm{fm}}$ from the muscle meter measurements. These documented differences for $m_{\mathrm{fm}}$ in wild birds or in captive birds subjected to ecologically relevant treatment indicate that phenotypic changes in the flight muscle mass frequently occurs in response to exercise, seasonal acclimatization, migration and/or moult and that those phenotypic mass changes could be detected by estimation of $m_{\mathrm{fm}}$ using the "musclemeter".

The "muscle-meter" device has been used to measure the change in flight muscle shape in several studies of birds, although none of these studies predicted $m_{\mathrm{fm}}$ from measured $\mathrm{mm}_{\text {score }}$ because no validation study like that presented here had been completed. For example, Schmidt-Wellenburg et al. $(2007 ; 2008)$ reported changes in $\mathrm{mm}_{\text {score }}$ of up to $0.55 \mathrm{~mm}$ for rose-colored starlings (Sturnus roseus) before and after a 6-hour flight in a 
windtunnel (Schmidt-Wellenburg et al. 2008). Bize et al. (2007) used the "muscle-meter" (mouth gap of $10 \mathrm{~mm}$ ) to determine changes in flight muscle shape in alpine swifts (Apus $m e l b a$ ) in response to a prolonged period of inclement weather. They documented a rapid decrease in $\mathrm{mm}_{\text {score }}$ of about $1.4 \mathrm{~mm}$ during inclement weather. European starlings that experienced rich, intermediate or poor foraging environments showed marked differences in $\mathrm{mm}_{\text {score }}$ of as much as $1.08 \mathrm{~mm}$ (Wiersma et al. 2005). Unfortunately, Wiersma et al. (2005) used a mouth gap of $6 \mathrm{~mm}$ for their muscle meter whereas we used a wider mouth gap of $10 \mathrm{~mm}$. Therefore, we are not able to estimate the actual change in muscle mass of the starlings from the data provided by Wiersma et al. (2005). We recommend that standard mouth gaps be used for each species so that results from different studies are most comparable. Clearly, the muscle meter detects significant changes in flight muscle shape that, given validation studies such as ours, can be used to predict changes in flight muscle mass. In concert with a calibration like the ones presented here for European starlings and garden warblers, precise estimates of $m_{\mathrm{fm}}$ and $m_{\mathrm{fm}}$ changes are possible that will help to contribute to the understanding of the phenotypic mass changes of the flight muscle.

\section{Acknowledgements}

The "muscle-meter" development started in 1996 when H.B, H.K and U.B developed the first prototype. We thank Franz Antoni and Klaus Pichler for their excellent support constructing the "Muscle-meter" and their help in finding solutions to simplify the measurement envisioning an easy to handle device. Josef Chernichko and other members of the Azov-Black Sea Ornithological Station, Ukraine made the collection of garden warblers possible. We thank Chris Guglielmo, and other "AFAR" members, for their generous support of the European starling project, and Lillie Langlois, Michelle Boyles and Alexander Gerson for their contributions in running the experiment. David Swanson and an anonymous reviewer provided constructive comments that helped to improve the manuscript. The research project on starlings performed in Canada was approved by the University of Western Ontario Animal Use Sub-Committee (Starlings, protocol \# 2006011-04). The field trip to Ukraine was funded by an ESF-travel grant to U.B., the research on European starlings was funded by a NSF-research grant to S.McW. 


\section{References}

Bairlein F (1987) Nutritional requirements for maintenance of body weight and fat deposition in the long-distance migratory garden warbler, Sylvia borin (Boddaert). Comp Biochem Physiol A 86:337-347

Bairlein F (1991) Body mass of Garden Warblers (Sylvia borin) on migration: a review of field data. Die Vogelwarte 36:48-61

Bairlein F (1995) Manual of field methods ESF (http://www.ifvvogelwarte.de/ESF/manual.pdf)

Bauchinger U, Biebach H (1998) The role of protein during migration in passerine birds. Biol Conserv Fauna 102:299-305

Bauchinger U, Biebach H (2001) Differential catabolism of muscle protein in garden warblers (Sylvia borin): flight and leg muscle act as a protein source during longdistance migration. J Comp Physiol B 171:293-301

Bauchinger U, Biebach H (2005) Phenotypic flexibility of skeletal muscles during longdistance migration of garden warblers: muscle changes are differentially related to body mass. In: Goymann W, Jenni-Eiermann S, Bauchinger U (eds) Analysis of hormones in bird droppings and optimality in bird migration. Ann NY Acad Sci 1046:271-281

Bauchinger U, Biebach H (2006) Transition between moult and migration in a longdistance migratory passerine: organ flexibility in the African wintering area $\mathbf{J}$ Ornithol 147:266-273

Bauchinger U, Wohlmann A, Biebach H (2005) Flexible remodeling of organ size during spring migration of the garden warbler (Sylvia borin). Zoology 108:97-106

Biebach H (1998) Phenotypic organ flexibility in garden warblers Sylvia borin during long-distance migration. J Avian Biol 29:529-535

Bize P, Klopfenstein A, Jeanneret C, Roulin A (2007) Intra-individual varation in body temperature and pectoral muscle size in nestling Alpine swifts Apus melba in 
response to an episode of inclement weather. J Ornithol 148:387-393

Bolton M, Monaghan P, Houston DC (1991) An improved technique for estimating pectoral muscle protein condition from body measurements of live gulls. Ibis $133: 264-270$

Burnham KP, Anderson DR (2002) Model selection and multi-model inference: a practical information theoretic approach. Springer-Verlag, New York

Calder WA (1984) Size, Function, and Life History. Havard University Press. Cambridge, MA.

Cottam M, Houston D, Lobley G, Hamilton I (2002) The use of muscle protein for egg production in the Zebra Finch Taeniopygia guttata. Ibis 144:210-217

Dietz MW, Dekinga A, Piersma T Verhulst S (1999a) Estimating organ size in small migrating shorebirds with ultrasonography: An intercalibration exercise. Phys Biochem Zool 72:28-37

Dietz MW, Piersma T, Dekinga A (1999b) Body-building without power training: Endogenously regulated pectoral muscle hypertrophy in confined shorebirds. J Exp Biol 292:2831-2837

Dietz MW, Piersma T, Hedenström A, Brugge M (2007) Intraspecific variation in avian pectoral muscle mass: constraints on maintaining manoeuvrability with increasing body mass. Funct Ecol 21:317-326

Fry CH, Ferguson-Lee IJ, Dowsett RJ (1972) Flight muscle hypertrophy and ecophysiological variation of yellow wagtail Motacilla flava races at Lake Chad. J Zool 167:293-306

Gaunt AS, Hikida RS, Jehl JR, Fenbert L (1990) Rapid atrophy and hypertrophy of an avian flight muscle. Auk 107:649-659

Hartman FA (1961) Locomotor mechanisms of birds. Smithson. Miscell. Coll. 143:1-91.

Houston DC, Donnan D, Jones PJ (1995) Use of labeled methionine to investigate the contribution of muscle proteins to egg-production in zebra finches. J Comp Physiol B 165:161-165.

Hume ID, Biebach H (1996) Digestive tract function in the long-distance migratory garden warbler, Sylvia borin. J Comp Physiol B 166:388-395

Jenni L, Jenni-Eiermann S (1998) Fuel supply and metabolic constraints in migrating birds. J Avian Biol 29:521-528 
Jones PJ, Ward P (1976) Level of reserve protein as proximate factor controlling timing of breeding and clutch-size in red-billed quelea Quelea quelea. Ibis 118:547-574

Lessels CM, Boag PT (1987) Unrepeatable Repeatabilities: A common Mistake. Auk 104:116-121

Lindtsröm Å, Kvist A, Piersma T, Dekinga A, Dietz MW (2000) Avian pectoral muscle size rapidly tracks body mass changes during flight, fasting and fuelling. J Exp Biol 203:913-919

Marsh RL (1984) Adaptations of the gray catbird Dumetella carolinensis to long-distance migration: flight muscle hypertrophy associated with elevated body mass. Physiol Zool 57:105-117

Nyeland J, Fox AD, Kahlert J, Therkildsen OR (2003) Field methods to assess pectoral muscle mass in moulting geese. Wildlife Biol 9:155-159

Piersma T, Drent J (2003) Phenotypic flexibility and the evolution of organismal design. TREE 18:228-233

Piersma T, Lindström Å. (1997) Rapid reversible changes in organ size as a component of adaptive behaviour. TREE 12:134-138

Schmidt-Wellenburg CA, Biebach H, Daan S, Visser GH (2007) Energy expenditure and wing beat frequency in relation to body mass in free flying Barn Swallows (Hirundo rustica). J Comp Physiol B 177:327-337

Schmidt-Wellenburg CA, Engel S, Visser GH (2008). Energy expenditure during flight in relation to body mass: effects of natural increases in mass and artificial load in Rose Coloured Starlings. J Comp Physiol B 178:767-777

Schwilch R, Grattarola A, Spina F, Jenni L (2002) Protein loss during long-distance migratory flight in passerine birds: adaptation and constraint. J Exp Biol 205:687695

Scott I, Selman C, Mitchell PI, Evans PR (2001) The use of total body electrical conductivity (TOBEC) to determine body composition in vertebrates. In: Speakman JR (ed) Body composition analysis of animals: a handbook of nondestructive methods. Cambridge University Press, Cambridge. 127-160

Selman RG, Houston DC (1996) A technique for measuring lean pectoral muscle mass in live small birds. Ibis 138:348-350 
Skagen SK, Knopf FL, Cade BS (1993) Estimation of lipids and lean mass of migrating sandpipers. Condor 95:944-956

Snow DW, Perrins CM, Doherty P, Cramp S (1998) Birds of the Western Palearctic. BWPi 2.01. Oxford University Press.

Swaddle JP, Biewener AA (2000) Exercise and reduced muscle mass in starlings. Science 406:585-586

Swanson DL (2010) Seasonal metabolic variation in birds: functional and mechanistic correlates. Current Ornithology 17:75-129

Svensson L (1992) Identification guide to Europe passerines, $4^{\text {th }}$ edn. Published by the author, Sturegatan 60, Stockholm, Sweden

Wiersma P, Salomons HM, Verhulst S (2005) Metabolic adjustment to increasing foraging costs of starlings in a closed economy. J Exp Biol 208:4099-4108

\section{Legend}

Figure 1

"Muscle-meter" and mounted caliper used to measure the shape of the flight muscle. Left top image shows three "muscle-meter" devices of which two have a free gap of $6 \mathrm{~mm}$ (A1) and one has a free gap of $10 \mathrm{~mm}$ (A2). The larger gap is used for bigger passerines birds like starlings, while the $6 \mathrm{~mm}$ gap is used for measurements on smaller sized birds, like the garden warbler. Picture on the top right demonstrates handling of the "muscle-meter", with the front panel sliding freely above the back panel. The front panel is then placed perpendicular on the flight muscle of a bird, which is held horizontally in the alternate hand (see bottom left picture). The location where the "Muscle-meter" is placed on the flight muscle is defined as the middle of the Carina sterni between its posterior and anterior end points. The "muscle-meter" is lowered perpendicularly onto the flight muscle until the back panel rests on the Carina sterni. This position of the muscle meter is now secured by pressing the free thumb of the hand that is holding the "musclemeter" against the front panel thereby locking the position of the "muscle-meter" (see 
bottom middle picture), and subsequently by closing the screw with a finger from the hand that holds the bird (see bottom right picture). The distance measured between the back panel (= level of the Carina sterni) and the front panel that measures the shape of the muscle $\left(\mathrm{mm}_{\text {score }}\right.$ in the muscle sketch) is now fixed at the lower part of the "muscle-meter". This distance is similar to the distance between the two panels at the upper end of the "muscle-meter", because both panels have equal length. The upper part of the "musclemeter" is now pushed gently into the slide at the measuring device B that holds a mounted caliper and the final $\mathrm{mm}_{\text {score }}$ is read from the caliper display. The caliper is mounted onto a metal block to provide stability and allows the measurement to be performed with one hand only, with the other hand still holding the bird. Before a set of measurements is recorded the calibration tool $\mathrm{C}$ is pushed into the slide and the value is set to zero to calibrate the caliper and its position in the device. The caliper is mounted in the measuring device $B$ in a way that the zero point already represents an input tension, i.e. without the calibration tool $\mathrm{C}$ the caliper reads a value > zero. We used an input tension of $0.14 \mathrm{~mm}$; actual values for the $\mathrm{mm}_{\text {score }}$ are read as negative values so that increasing values signify increasing muscle bulging. Using three repeated $\mathrm{mm}_{\text {score }}$ measures to create a mean value reduces the likelihood of odd values to find their way into the data set. 